\title{
Reform Strategies for College Ideological and Political Teaching Based on MOOC (Massive Open Online Course)
}

\author{
Kena Wang ${ }^{1}$, Guohong Wang ${ }^{2}$ \\ ${ }^{1,2}$ School of Marxism Studies, Qiqihar Medical University, Qiqihar, Heilongjiang, 161006, China
}

Keywords: MOOC; college ideological and political course; teaching reform

\begin{abstract}
The ideological and political course in China's colleges and universities has become one of the most important required courses, which plays a very positive guiding role in the formation of young students' outlook on life and value. In the Internet era, a new teaching method has emerged in the ideological and political education course, that is, MOOC, which requires us to deeply analyze the teaching idea of MOOC, find the connection between MOOC and the teaching reform of college ideological and political course, and then find better strategies for improving the teaching reform of college ideological and political course.
\end{abstract}

\section{Introduction}

Since the appearance in China in 2013, MOOC has attracted a lot of attention with its remarkable advantages, such as openness, diversification and low cost. The ideological and political course is a common required course, and its shareability has promoted it to be a very important course in the MOOC platform. However, MOOC is not suitable for all colleges. In the colleges that do not have the conditions or are not suitable for the implementation of MOOC, the advantages of MOOC can be used to perfect their traditional classroom teaching methods and improve the college students' cultural consciousness. Nowadays, for the education development, the concept that fundamentally depends on the reform has been deeply rooted in people's mind, it must be based on the modern information technology, and the teaching content, method and means of MOOC which has been widely accepted and praised by modern people shall be used. The application of educational informationization to the promotion of the educational modernization is a necessary measure to solve the problems that affect the education development and drive the innovation and reform of education in China. After the rise of MOOC, the teaching of ideological and political course in colleges must be reformed correspondingly, which requires us to think deeply about the application of MOOC in the classroom teaching of ideological and political course, so as to promote the realization of the transformation of the classroom teaching of ideological and political course in a rational and critical way, and continuously improve its attraction and appeal.

\section{Significance of Teaching Reform of College Ideological and Political Course with MOOC}

First of all, some new changes have taken place in the college students' behavioral habits in the Internet era. It is disclosed in the 41st China Statistical Report on Internet Development that up to December, 2017, the number of netizens in China has reached 772 million, and the proportion of mobile netizens has reached $97.5 \%$. In the network era, college students are the so-called digital aborigines symbiotic with the network. Network is the first platform for them to get relevant information and knowledge. The contemporary college students are used to getting relevant information through network, and they like using some social media such as QQ, microblog and WeChat for communication and have very distinct personal labels and unique views on the world. In their eyes, the restriction on Internet is intolerable. As a result, the classroom has become an important battleground for teachers to try their very best to take back students' attention from the mobile phones. The current college students are not willing to accept the compulsory educational 
mode for the ideological and political course, nor are they satisfied with the classroom teaching mode with teaching as the subject, which requires the teachers of the ideological and political courses to pay more attention to the great influence of Internet on the learning state of college students, and provide them with more efficient Network communication channel, so as to meet the needs of their personalization.

Secondly, MOOC has a great impact on the traditional ideological and political education. Although the online courses can not replace the traditional classroom teaching, they will push the reform of educational system and constantly improve the classroom teaching quality in colleges. Otherwise, the ordinary colleges will become the laboratories and tutorial rooms of the excellent colleges. MOOC appears in the background of the continuous development of modern digital technology, which is in line with the good development trend of the education business in the information age. The popularization of network and the continuous progress of functions of mobile phones have promoted the great development of MOOC. There are some differences and similarity between MOOC and the video open class. The similarity between them is that both of them are explained by teachers through videos, but usually the videos for MOOC are short between five and fifteen minutes, and some test questions are arranged between the front video and the later one, which can help the students improve their attention and help the learners deeply understand the knowledge that has just been learned in the form of test questions. As a result, the work that teachers correct the examination papers can be replaced by computers completely. The computer analysis software can test college students' classroom behaviors automatically, and the software designers can master the learners' learning status according to the statistical data, thus helping teachers improve the teaching reform strategy pertinently, and then improving the teaching quality of MOOC. MOOC not only has a strong advantage in the resource sharing, but also has the initiative in teaching methods and the interestingness in classroom teaching. The time and site of MOOC can be arranged at will, and students can choose time freely for preview, discussion and interaction until the final test is completed.

Thirdly, the MOOC mode can adapt to the demands in the Internet era. With the development of Internet Plus, network tools have comprehensively changed and overturned the fixed and traditional teaching mode of the college ideological and political course, which has greatly affected students' thinking habits and value orientation. Only the reform of college Ideological and political teaching keep pace with the times and is carried out deeply, this course can follow the current era development pace and be accepted by more college students. On the one hand, the modern information technology provides new possibility for the reform of the teaching form and the expansion of teaching approach for the college ideological and political course, promotes the focus of ideological and political education towards to the network gradually, and then transfer to MOOC, thus making MOOC become a promising teaching method. On the other hand, the struggle for the speaking right of network ideology in the era of big data is becoming more and more intense. College students not only receive the positive energy transmitted by the teachers in the teaching process, but also will be attacked by all kinds of thought of non-Marxism and even anti-Marxism. In this case, how to apply Marxism-Leninism to solve various practical problems under the influence of more complicated ethos, so as to clarify the dominant position of Marxism in the diversification and let MOOC play a greater effect shall be considered.

\section{Prominent Advantages of Introduction of MOOC to College Ideological and Political Teaching}

Firstly, MOOC has the advantages of innovation and shareability. MOOC can be said to be an innovative teaching method, so it also has an obvious characteristic of innovation. As a brand-new teaching method, MOOC implements the education and teaching evaluation, so that the college students can participate in the education and teaching system independently and show their main dominant position. Meanwhile, MOOC can achieve the resource sharing, so that the college students can access to the advanced teaching methods from various places and extracurricular knowledge to 
constantly improve their quality.

Secondly, the content of MOOC has the advantage of high quality. So to speak, MOOC collects the best teachers from all parts of the country, and every teacher teaches students in his or her own adept field with strong specialty. College students can carry out the explanation by MOOC mode, so as to acquire new knowledge and theories, and then further improve their own quality and ability. The teachers of college ideological and political courses also can learn the advanced teaching thought from other teachers, and absorb and convert them into the teaching contents with their own distinctive features combined with their own educational and teaching characteristics.

Thirdly, MOOC has the advantage of humanization. Different from the traditional classroom teaching methods for the ideological and political course, MOOC pays more attention to college students' autonomous learning. College students can choose the teaching content in a planned and purposeful way according to the content that they need to learn or the improper links, so that the teaching process can become more individualized, be more in line with the psychological needs of college students, and easier to improve their learning enthusiasm. Of course, college students also can constantly change the fixed learning styles in the autonomic learning process, so as to find the teaching methods more suitable for themselves, and constantly improve the academic record of this course.

\section{Strategies for Teaching Reform of College Ideological and Political Course under MOOC}

Firstly, update the teaching concept practically and give consideration to both of the social needs and students' personal learning needs. Only pay attention to the social function of college ideological and political teaching, but ignore the college students' specific learning needs, or pay too much attention to the college students' specific learning needs, but ignore the association attributes in the content of ideological and political education related the social moral education, all of which are obvious problems in the traditional classroom teaching of college ideological and political course. For these problem, the teachers in charge of the ideological and political education shall apply MOOC to the classroom better, update their teaching concepts completely, put the college students in the dominant position of the classroom teaching, and become the guiders and the fellow travelers of the knowledge of college ideological and political education. For example, when the college ideological and political educators explain the specific content related to the orientation of social behaviors by modern teaching methods such as MOOC, they shall closely combine the present social development state, and find the more comprehensive teaching resources that can meet the specific learning needs of the college students. Through the application of the combination of teaching resources that are more popular in the college students with MOOC in the ideological and political education, students can use it more flexibly. After the teachers can skillfully apply MOOC to the ideological and political teaching, they can improve the education and teaching quality immediately.

Secondly, continually improve the independent exploration ability and make good use of the modern network tools for education and teaching. The application of MOOC can separate the teachers from the students in the classroom of ideological and political education. Compared with the traditional classroom teaching methods, the MOOC education lacks the more realistic and practical scenes, thus asking for new and higher requirements for the college students and teachers' independent exploration of the ideological and political education knowledge. For example, when college students are learning the knowledge about outlook on life, value and others by MOOC, they shall regular their own learning state with strict self-discipline, and the teachers shall strongly supervise them to develop some good habits, such as earnest preview before class, hardworking exploration in class and timely consolidation after class. When it is necessary, the relevant personnel of the education competent department shall increase the training and learning opportunities for the teachers in charge of the college ideological and political education, so that they can better master all kinds of knowledge related to MOOC and improve their ability of network education and teaching, thus laying a better foundation for the effective application of MOOC in the college education and teaching. 
Thirdly, energetically improve the education and learning process, and increase the utilization rate of educational resources. The institutions of higher learning shall carry out corresponding teaching reform in the setting form of ideological and political education. After the improvement based on MOOC, we can carry out the teaching activities to thousands of people at the same time, so that the overall scope of college ideological and political teaching can be expanded to the maximum limit.

Fourthly, actively establish a learning exchange system and improve the quality of college ideological and political teachers. Nowadays, more and more colleges have begun to pay close attention to the teaching of ideological and political course, and constantly strengthen the ideological and political education for the college students. However, because there are some gaps between different colleges in the richness degree and actual level of resources of the ideological and political course, the teaching of ideological and political course in China's colleges has been improved in general, but there are still many colleges lacking high-quality ideological and political teaching resources, and their teaching ability needs to be improved, which requires to establish a better resource sharing platform for the teachers of college ideological and political course, so as to carry out training, learning and exchanges better. MOOC happens to be such a suitable platform, which can promote the sharing of teaching resources and improve teachers' quality, so as to accelerate the reform of college ideological and political course.

Fifthly, make efforts to enhance technical support and help update the teaching methods for college ideological and political education. The teaching effect of college ideological and political course is mainly reflected in how to enable college students to form cognition better under the premise of understanding the knowledge. By the traditional teaching methods, students are difficult to learn deeply due to the limitation of classroom teaching time, but by the teaching mode based on MOOC, college students can learn in the spare time in any place. Meanwhile, because of the openness of network, teachers can test the students according to the current social hot spots, and eliminate doubts and confusions for students as quickly as possible, and communicate with students at any time.

\section{Conclusion}

In general, MOOC has adapted to the practical needs of the teaching of college ideological and political course to a great extent, and has good application value in the college ideological and political education. Based on MOOC, The teachers of college ideological and political courses can not give up their own educational characteristics, and shall look on the teaching mode of MOOC with an all-sided view. Due to the limitation of various objective factors, there are some problems in the application of MOOC teaching system in China, which requires the relevant educators to form a correct concept of education and teaching, effectively apply MOOC to the college ideological and political education by more scientific and efficient educational measures, and make it give full play to its role maximally.

\section{References}

[1] Gao Di, Application of MOOC in Moral Education in Western Colleges and Universities and Enlightenment to Construction of Ideological and Political Theory Courses in China's Colleges and Universities , Modern Distance Education, 2014 (2) .

[2] Sun Yingjun, Discussion on New Problems of Teaching Modes in Colleges and Universities in Background of MOOC, Journal of University of Shanghai for Science and Technology (social sciences version), 2015 (3).

[3] Yan Zhenwei, Opportunities and Challenges for Teachers of Ideological and Political Theory Courses in Colleges and Universities to Adapt to Teaching Form of MOOC , Journal of Inner Mongolia Normal University (educational science version), 2016 (9) .

[4] Yang Xin, Exploration of Reform Mode for Mixed Teaching of Ideological and Moral Cultivation 
and Legal Basis based on MOOC, Estate and Science Tribune, 2016 (19) .

[5] Guo Aohong, Research on Application of Flipped Classroom in Ideological and Political Theory Course under Background of MOOC, School Party Construction and Ideological Education, 2016 (20). 